

\title{
Barriers and motivations for participation in preventive vaccine clinical trials: Experience of 5 clinical research sites
}

M. Detoc, O. Launay, Christian Dualé, C. Mutter, J.-C. Le Huec, N. Lenzi, F. Lucht, A. Gagneux-Brunon, E. Botelho-Nevers

\section{To cite this version:}

M. Detoc, O. Launay, Christian Dualé, C. Mutter, J.-C. Le Huec, et al.. Barriers and motivations for participation in preventive vaccine clinical trials: Experience of 5 clinical research sites. Vaccine, 2019, 37 (44), pp.6633-6639. 10.1016/j.vaccine.2019.09.048 . hal-02460331

\section{HAL Id: hal-02460331 \\ https://hal.science/hal-02460331}

Submitted on 21 Dec 2021

HAL is a multi-disciplinary open access archive for the deposit and dissemination of scientific research documents, whether they are published or not. The documents may come from teaching and research institutions in France or abroad, or from public or private research centers.
L'archive ouverte pluridisciplinaire HAL, est destinée au dépôt et à la diffusion de documents scientifiques de niveau recherche, publiés ou non, émanant des établissements d'enseignement et de recherche français ou étrangers, des laboratoires publics ou privés.

\section{(c) (1) $\$$}

Distributed under a Creative Commons Attribution - NonCommerciall 4.0 International 


\title{
Barriers and motivations for participation in preventive vaccine
}

\section{clinical trials: experience of 5 clinical research sites}

\author{
M. Detoc ${ }^{1,2,3}$, O. Launay ${ }^{3,4}$, C. Dualé ${ }^{3,5}$, C. Mutter ${ }^{3,6}$, J-C. Le Huec ${ }^{7}$, N. Lenzi ${ }^{3}$, F. Lucht ${ }^{1,2,3}$, A. \\ Gagneux-Brunon ${ }^{1,2,3 *}$ and E. Botelho-Nevers ${ }^{1,2,3 *}$
}

${ }^{1}$ Clinical trial center, INSERM CIC 1408, University Hospital of Saint-Etienne, 42055 SaintEtienne, France

${ }^{2}$ Groupe Immunité Muqueuse et Agents Pathogènes (GIMAP), EA3064 - Medical School of Saint-Etienne, University of Lyon

${ }^{3}$.Inserm, F-CRIN, Innovative clinical research network in vaccinology (I-REIVAC), Paris, France

4. Université Paris Descartes, Sorbonne Paris Cité ; Inserm, CIC 1417 ; Assistance PubliqueHôpitaux de Paris, CIC Cochin Pasteur, Hôpital Cochin Broca Hôtel-Dieu, Paris, France

5. Centre de Pharmacologie Clinique (INSERM CIC1405), CHU Clermont-Ferrand, Clermont-Ferrand, France

${ }^{6}$. CIC Inserm 1434, CHU de Strasbourg, Strasbourg, France

${ }^{7}$ Polyclinique Bordeaux Nord Aquitaine, Unité Rachis, Université Bordeaux Deterca Lab, 15 rue Boucher, 33000 Bordeaux, France

*Participated equally to this work

Word count: 3017

Abstract: 248

Keywords: vaccine, vaccine clinical trial, motivations, barriers, participation, recruitment 
1 Barriers and motivations for participation in preventive vaccine

2 clinical trials: experience of 5 clinical research sites

3 
4

\section{Abstract}

Recruitment in preventive vaccine trials (PVT) is challenging due to common barriers to clinical research and lack of vaccine confidence. Identifying determinants of participation can help to improve recruitment. A prospective survey was conducted in 5 French clinical investigational sites. People asked to participate in a PVT were given a questionnaire whether they decided to participate or not in the trial. A total of 341 people answered the survey: 210 accepting and 131 declining to participate in a PVT. Acceptors were significantly younger (38.5 vs 54.9 years old), more likely to be involved in early phase trials, had a higher level of education $(\mathrm{p}<0.005)$ and a significantly better general opinion concerning vaccines $(92.3 \%$ versus $72.3 \%, \mathrm{p}<0.005)$ compared with those who declined. Factors associated with acceptance or refusal were evaluated in 224 people in the 4 sites where both groups were included. In a multivariate analysis, three factors: older age, having heard about PVT through multiple sources and financial incentives were significantly associated with refusal to participate in the PVT. A generally favourable opinion of vaccines was associated with acceptance. The main motivation for participation was altruism (93.2\%) whereas fear of side effects was at the forefront of the barriers (36.6\%). Information given by the physician was a key point for decision-making in $70.2 \%$ of those who accepted. In brief, vaccine hesitancy may decrease recruitment in PVTs; reinforcing altruism and quality of information given are key points in acceptance of participation in PVT.

Keywords: vaccine, vaccine clinical trial, motivations, barriers, participation, recruitment 


\section{Introduction}

Vaccination is one of the greatest successes in modern medicine, resulting in more than 2 to 3 million fewer deaths per year [1]. Development of new vaccines remains crucial in the context of outbreaks due to emerging pathogens [2] and is part of promising strategies to fight antimicrobial resistance and healthcare-associated infections [3]. Despite an increase in vaccine development [4] with more than 7300 vaccine trials registered in clinical trial.gov [5], vaccine clinical development remains time -and cost- consuming [6]. Despite lack of data on preventive vaccine trials (PVTs), recruitment failure is the primary reason for discontinuation in clinical drug trials, occurring in one out of five trials [7]. Due to the cost associated with the clinical development of a vaccine and the public health benefits expected, reaching optimal recruitment in PVTs is crucial.

In a web survey conducted in the US, likelihood of participating in a vaccine trial was found to be lower compared to a trial for new medication or a medical device among diagnosed volunteers [8], suggesting that participation in a PVT and therefore recruitment for these trials may be associated with specific factors that need to be studied more closely. In fact, vaccine hesitancy and doubts about vaccine safety in the general population [9] might have a negative impact on recruitment of volunteers in PVTs. Therefore, investigative teams working in PVTs may face common challenges to clinical trials in general such as mistrust of research, difficulties in recruitment, enrollment, and retention of study participants [10-12]. These teams may also be confronted with specific concerns about vaccines that have not yet been studied in depth. To date, barriers to participation in a vaccine trial, together with motivators, have been poorly evaluated and published studies mainly deal with HIV, HCV and HPV vaccines [13].

Identifying motivators and barriers may help investigators to address potential participants' concerns and to improve recruitment in these trials. In the present study, our aim is to identify factors associated with the acceptance or refusal to participate in PVTs (phases 1 
to 4) among healthy and diagnosed volunteers seen in five clinical vaccine investigational sites in France.

\section{Material and methods}

The study took place from September 2016 to March 2018 at 5 investigational sites among which 4 are part of I-Reivac "Innovative Clinical Research Network In Vaccinology" [14]. Consecutive potential participants who received a proposal to participate in a PVT in these centers, whatever their decision regarding participation in the trial, were asked to answer a survey. Eligible trials were PVTs of all study phases with (i) Institutional Review Board approval, (ii) ongoing recruitment, and (iii) whatever the infectious disease targeted by the vaccine studied. Early-phase studies were defined as phases 1 and 2a trials and later-phase studies as phases 2b and 3 (See Table 1). Early-phase PVTs were offered to healthy people and late-phase PVTs were offered to patients. Only PVTs conducted in adults were considered in this study.

Potential participants in a PVT who accepted to answer this survey received a selfadministered questionnaire with six demographical questions and sixteen questions that would differ slightly according to their decision regarding participation in the PVT. Demographical data and motivations or barriers to participation in the proposed PVT were requested. Willingness to participate in a hypothetical experimental preventive vaccine against HIV, HBV or influenza virus was also assessed. These 3 diseases were selected because HBV vaccine has been controversial in France, vaccine coverage against seasonal influenza remains low, and HIV is a frightening disease as far as the general public is concerned. All 3 diseases can be contracted anywhere. All questions were previously validated and tested by volunteers and infectious diseases specialists involved in the study.

Ethics. The local ethics committee of the University Hospital of Saint-Etienne approved these anonymous surveys in February 2016 (number IRBN732015/CHUSTE). A declaration to the 

Libertés) was made.

82 Statistics. To compare characteristics of acceptors and decliners, differences between proportions were analyzed by chi-squared test or Fisher's exact test. To identify factors associated with acceptance or refusal to participate, we did not use the data of people from site number 2, as the latter could only collect questionnaires from acceptors. A p-value below 0.05 was considered to be statistically significant. To adjust for confounding factors, we conducted a multivariate analysis to test association between the explanatory variables and the decision to accept participation in a PVT with a p-value below 0.2 significance level in the univariate analysis. The software used for collecting recorded data was Microsoft Excel and SPSS software (NYC 24.0) was used for statistical analysis. 


\section{Results}

Table 1 summarizes the population distribution between each clinical research site and features of the proposed PVTs. Nine different PVTs were active at the time of the survey in the 5 sites (see Table 1). During the study period, approximately five hundred individuals were asked to participate in a PVT at the 5 sites.

\section{Respondents to the survey and their characteristics}

Table 2 summarizes the main characteristics of survey respondents. A total of 341 potential participants in a PVT answered the survey: 210 accepted the proposal to enroll in a PVT (acceptors) and 131 declined the proposal (decliners). For site 2, only acceptors replied to the questionnaire. The majority were female $(68.9 \%, 235$ out of 341$)$ and the mean age was 45.1 years \pm 18.2 . Distribution of acceptors was balanced between early and late phases. Two hundred and twenty-four respondents $(66.9 \%)$ were acquainted with clinical research and 69 (20.4\%) had previously participated in a clinical trial. Fifty-nine respondents (17.4\%) asked their general practitioner (GP)'s for advice regarding their participation in the PVT and 67.8 $\%$ (40/59) followed it. Decliners were significantly older, had a lower level of education and in general had more children than acceptors (See Table 2).

\section{Factors associated with agreement to enroll in a PVT}

Only participants on sites $1,3,4$ and 5 were included in this analysis $(n=224)$. People included in this analysis were invited to participate mainly in late-phase trials. In the univariate analysis presented in Table 3, Older age ( $\mathrm{OR}=0.97$ (95\% IC: $0.95-0.98$ - for one year increase in age $(\mathrm{p}<0.005))$, having heard about PVT through multiple sources $(\mathrm{OR}=0.09$ (95\% IC=0.01-0.75), $\mathrm{p}=0.006)$ and proposal for a financially compensated study $(0.48(95 \%$ $\mathrm{IC}=0.28-0.80)) \mathrm{p}<0.005)$ were negatively associated with accepting participation to the PVT. In the multivariate analysis (after adjustment for age, clinical research awareness, advice from GPs, having children, having heard about PVT through multiple sources, and financially compensated studies), these confounding factors were also associated with refusal to 
participate. In the univariate and multivariate analyses, having a favorable opinion about

119 vaccines was the only factor associated with agreement to participate in the PVT $(\mathrm{p}<0.005$,

120 OR: $4.98(95 \% \mathrm{CI}=1.88-13.2))$.

121

122

123

124

125

126

127

128

129

130

131

132

133

Acceptors ' motivations

Two hundred and six acceptors (98\%) from the five research sites answered the specific questionnaire about their reasons for participating in a PVT, 131(63.6\%) people in earlyphase trials (healthy people), $75(36.4 \%)$ in late-phase trials (patients). Details are shown in

Table 4. Altruism was the main reason that encouraged 192 of them (93.2\%) to consent to participation in a PVT with no difference between healthy and patient participants. Financial incentives encouraged 118 of them (57.3\%) to accept the proposal; this was a motivation for 110 healthy participants $(84 \%)$ and $8(10.7 \%)$ patients $(\mathrm{p}<0.005)$. The direct potential benefit of being protected by the vaccine was a reason for agreeing to participate for 80 respondents (39.3\%) -38 (50.7\%) patients vs $42(32.1 \%)$ healthy participants $(\mathrm{p}=0.008)$. The fact that they felt at risk for the targeted disease in the study was declared by 81 of them (38.8\%) -36 (48.0\%) patients vs $45(34.4 \%)$ healthy participants ( $\mathrm{p}=0.054)$. Points that helped them to accept enrollment were the quality of the information provided by the physician for 145 respondents (70.4\%) without differences between healthy and patient participants, the subject of the trial for $124(60.2 \%)-48 \%$ of patients vs $67.2 \%$ of healthy participants $(p=0.007)$, the medical follow-up for 120 (58.2\%) of them with no difference between healthy participants and patients. Financial incentive was a key point for 98 (47.6\%) -88 (67.2\%) healthy participants vs $10(13.3 \%)$ patients $(\mathrm{p}<0.005)$. Their GP's opinion was a key point for 63 out of the 206 respondents (30.6\%), particularly in patients, 34 (45.3\%) compared to healthy participants $(\mathrm{n}=29,22.1 \%),(\mathrm{p}<0.005)$.

\section{Barriers for decliners}

The reasons for declining the opportunity to participate in a PVT given by the 131 decliners $94(71.8 \%)$ potential patient participants and 37 potential healthy participants $(28.2 \%)$ - are 
shown in Table 3. Key barriers to uptake were firstly the fear of side effects for 48

145 participants $(36.6 \%)$ with no difference between potential healthy and patient participants 146 (respectively $38(40.4 \%)$ patients and $10(27 \%)$ healthy participants $(\mathrm{p}=0.15))$. Difficulties in

147 attending protocol appointments were reported as a barrier by 38 of them (29\%) (respectively

$14820(21.3 \%)$ and $18(48.6 \%)$ potential patient and healthy participants). Twenty-six (19.8\%)

149 were afraid of vaccine components, with a significant difference between healthy people $150(n=14,37.8 \%)$ and patients declining participation $(n=12,12.8 \%), p<0.005)$.

151

152 Attitudes according to the different scenarios offered

153 Decliners were asked if their answer would have been different if the targeted disease affected 154 them: this was the case in $27.3 \%$ (35/128) of respondents who might have agreed to 155 participate in the PVT. The same proportion would have agreed to enroll in the clinical trial if 156 the drug tested had not been a vaccine. Among acceptors, 29\% (59/195), 44.5\% (90/202), $15742.4 \%$ (86/ 203) would have declined to participate if the evaluated vaccine had been 158 respectively against influenza, HIV and HBV. Among the decliners $9.2 \%(12 / 130), 16 \%$ 159 (21/130), 26.4\% (34/129) would have agreed to participate if the evaluated vaccine had been 160 respectively against $\mathrm{HIV}, \mathrm{HBV}$, influenza. 
Our survey identified motivations and barriers to participation in a PVT among adults asked to participate in trials studying real vaccines in development. These factors have been rarely studied in PVTs in general. A recent study explored barriers to enrollment in PVTs from the point of view of investigators with experience in PVTs [15], not among people approached for participation in PVTs. Previous studies that evaluated these factors among potential participants usually focused on a unique vaccine trial in young adults, or were conducted considering hypothetical vaccine trials [13]. The people interviewed in our study, were potential participants in an actual PVT carried out at 5 French clinical research sites. Nine PVTs with different targeted diseases and different phases of development were proposed.

Factors and motivators associated with participation in a PVT have been identified in this wide-ranging survey. Our study showed that having a favorable opinion about vaccines was the only independent factor associated with agreement to enroll in a PVT, emphasizing the impact of opinions about vaccines on recruitment in a PVT. Vaccine hesitancy was in fact listed as one top barrier with "some effect" on PVT recruitment by researchers in Belgium [15]. In addition, Rikin et al. observed in 191 elderly Hispanic people, that being vaccinated against seasonal flu the year before increased by 2.6 times the acceptance of participation in a PVT [16]. In the same way, we also observed that a third of the decliners declared they would participate in a trial if the drug tested was not a vaccine. This difference in willingness to participate in a trial according to the type of product tested was previously reported in a US study [8]. Therefore gaining a better understanding of their opinion on vaccines by people asked to participate in a PVT may help to target favorable people and increase recruitment.

Altruistic motivation has been shown to play an important role in vaccination decisions [17]. In clinical research -whether in non-vaccine trials [18] or in PVTs [13]- altruism has been shown to be a major motivation for participation in trials, a fact we also observed here. To 
target people with altruistic motivation may improve recruitment. Promoting altruistic participation in PVTs could prove an effective strategy in the promotion of clinical research vaccination as observed in blood donations [19].

We also identified factors and barriers associated with refusal to participate in PVTs, older age being the major independent factor associated with refusal. Recruiting the elderly in PVTs may thus be challenging, as has also been reported by researchers in the vaccine field [15]. Therefore this point seems crucial since among all 9 trials conducted during our study period, 4 included elderly participants. Some vaccine-preventable diseases affect older people in particular and many vaccines in development target the elderly [3]. Older people who considered they were in good health were more likely to participate in a PVT than those who considered their health as poor [20]. Regardless of age, the way older people see their health may influence their participation in PVT and this should be taken into account before enrollment in a PVT.

Financial incentives for participating in a PVT were negatively associated with acceptance in our survey, notably in late-phase trials, as frequently and previously reported [13]. This observation may be due to the inclusion of participants $>40$ years-old in our analysis whereas financial incentives are a stronger motivation for young people [21]. Indeed, in a study with elderly Hispanic people where different scenarios were proposed to potential participants in a PVT against seasonal influenza [16], when an $\$ 80$ financial incentive was proposed, the proportion of people that agreed to participate decreased by $12.2 \%$ compared to no incentive. However, when we included acceptors, enrolled mainly in early-phase studies, in the analysis, financial incentives helped $49 \%$ of them to make a decision. This is probably linked to the fact that only early-phase studies received financial incentives [22] and in these phases participants are frequently healthy volunteers.

Having heard about the PVT through multiple sources was found as the third independent factor for refusal here. It may be due to the fact that the people interviewed were approached 
for participation mainly in late phase trials and were not coming spontaneously to the center.

217

218

219

220

221

222

223

224

225

226

227

By contrast in other settings, the use of multiple recruitment sources simultaneously was found to be beneficial to recruitment [23].

Fear of side effects was at the forefront of the barriers to participation in a PVT as we have previously reviewed [13] and this was pointed out by more than $30 \%$ of decliners. Safety concerns about vaccines were also reported for over $40 \%$ of French participants in the vaccine confidence project [9]. It seems thus to be very important for investigators to be transparent and clearly describe available safety results to participants $[24,25]$.

The purpose of the PVT was also found to be a key factor in decision-making (See Table 3), as highlighted by the fact that acceptors or decliners would change their minds if the proposed trial was related to HIV, HBV or influenza trials. These data are concordant with previous results summarized by our team [13]. These findings underline the role of knowledge about disease and the perceived risk for the acceptance of a vaccine [26]. Indeed, the acceptance of a possible vaccine is associated with the knowledge of the usefulness of vaccines [27]. So it would be important during study presentation to potential participant to insist on available safety data and to explain in detail the targeted diseases.

Most of the acceptors obtained information from the medical staff at the research site, and the quality of information helped $70 \%$ of the acceptors to make their decision. The research clinic staff are the major source of information for potential participants, particularly in the elderly as previously shown [20]. In our panel, $20 \%$ of respondents asked for their GP's opinion on their participation in a PVT and followed it in more than $50 \%$ of cases. In the US, $55 \%$ of the participants aged over 60 years in an influenza PVT, considered that their physician needs to be comfortable with their participation [20]. In parallel to this study, we conducted a study in primary care physicians and treating specialists and around $60 \%$ of them wanted to be involved in the decision-making by their patients about participation in PVT [28]. However, physicians considered they were undertrained about clinical research, and would like more 
information about the PVT to participate in the decision-making process [28]. It would be

243 important to inform the patient's GP of the proposal made to his or her patient. Explaining the 244 protocol to them could allow a more constructive exchange in the decision-making process. Our study has several limitations. Due to the study design, the population of participants was quite heterogeneous. We chose to include potential participants for different types of PVT (Phases 1 to Phases 3) as well as healthy and diagnosed volunteers to bring insights into motivations and barriers to participation in PVTs in general. In fact previous data had only focused on a specific vaccine. Moreover our study was performed in the real-life setting of investigational sites and reflected the challenges that investigators involved in vaccinology have to face. One of the sites did not have access to participants who refused because their proposed trials mainly involved healthy volunteers who presented themselves spontaneously. To reduce this potential bias we did not integrate their observations in the analysis of factors associated with acceptance. Although we did not have full details on people who refused to answer this survey, it is likely that the response rate was lower among people who declined participation in PVTs. This can suggest that barriers to participation in PVTs have not yet been fully explored since decliners seem difficult to reach for interview.

In conclusion, in this study that interviewed potential participants in real PVTs, we observed that the way vaccines are seen by the public has an impact on recruitment. Fostering vaccine-confident participants may improve recruitment in PVTs. Financial incentives and multiplication of information sources are not suitable for all types of potential participants, particularly in trials including the elderly. The quality of the information given by the medical staff in the clinical research center is a crucial issue, and the possibility for shared decisions with primary care physicians reinforces the need for specific training of all physicians regarding clinical research.

\section{Conflict of interest}


268 The authors declare that they have no conflict of interest.

269 Author's contributions

270 MD, EBN conceived the study and the questionnaire. MD, AGB and EBN carried out data

271 analysis. All authors critically reviewed this manuscript. All authors read and approved of the

272 final manuscript.

273 Acknowledgments

274 The authors wish to thank i-Reivac sites for their participation and their help in sending the 275 survey, particularly clinical research associates of the sites: Ms S.Bouillau, Ms S. Bendele, Ms 276 N. Nedjaai, Ms S. Saleh-Mghir, Ms G. Badre and Mr S. Bourret. The authors also wish to 277 thank Mr Philippe Michelucci and Ms Glynn Thoiron for providing English editing of the 278 manuscript 
[1] WHO | Immunization. WHO n.d. http://www.who.int/topics/immunization/en/ (accessed August 27, 2018).

[2] Rauch S, Jasny E, Schmidt KE, Petsch

B. New Vaccine Technologies to Combat Outbreak Situations. Front Immunol 2018;9. doi:10.3389/fimmu.2018.01963.

[3] Gagneux-Brunon A, Lucht F, Launay O, Berthelot P, Botelho-Nevers E. Vaccines for

[6] Gouglas D, Thanh Le T, Henderson K, Kaloudis A, Danielsen T, Hammersland NC, et al. Estimating the cost of vaccine development against epidemic infectious diseases: a cost minimisation study. Lancet Glob Health 2018;6:e1386-96. doi:10.1016/S2214109X(18)30346-2.

[7] van den Bogert CA, Souverein PC, Brekelmans CTM, Janssen SWJ, Koëter GH, Leufkens HGM, et al. Recruitment failure and futility were the most common reasons for discontinuation of clinical drug trials. Results of a nationwide inception cohort study in the Netherlands. J Clin Epidemiol 2017;88:140-7. doi:10.1016/j.jclinepi.2017.05.001.

[8] Cobb EM, Singer DC, Davis MM. Public interest in medical research participation: differences by volunteer status and study type. Clin Transl Sci 2014;7:145-9. doi:10.1111/cts.12142. 
[9] Larson HJ, de Figueiredo A, Xiahong Z, Schulz WS, Verger P, Johnston IG, et al. The State of Vaccine Confidence 2016: Global Insights Through a 67-Country Survey. EBioMedicine n.d. doi:10.1016/j.ebiom.2016.08.042.

[10] Tramm R, Daws K, Schadewaldt V. Clinical trial recruitment--a complex intervention? J Clin Nurs 2013;22:2436-43. doi:10.1111/jocn.12145.

[11] Buchbinder SP, Metch B, Holte SE, Scheer S, Coletti A, Vittinghoff E. Determinants of enrollment in a preventive HIV vaccine trial: hypothetical versus actual willingness and barriers to participation. J Acquir Immune Defic Syndr 1999 2004;36:604-12.

[12] McDonald AM, Knight RC, Campbell MK, Entwistle VA, Grant AM, Cook JA, et al. What influences recruitment to randomised controlled trials? A review of trials funded by two UK funding agencies. Trials 2006;7:9. doi:10.1186/1745-6215-7-9.

[13] Detoc M, Gagneux-Brunon A, Lucht F, Botelho-Nevers E. Barriers and motivations to volunteers' participation in preventive vaccine trials: a systematic review. Expert Rev Vaccines 2017;16:467-77. doi:10.1080/14760584.2017.1297706.

[14] Welcome to the I-REIVAC website | I-REIVAC - Innovative Clinical Research Network In Vaccinology n.d. https://ireivac.fr/en/welcome-i-reivac-website (accessed March 7, 2019).

[15] Harrington L, Van Damme P, Vandermeulen C, Mali S. Recruitment barriers for prophylactic vaccine trials: A study in Belgium. Vaccine 2017;35:6598-603. doi:10.1016/j.vaccine.2017.10.041.

[16] Rikin S, Shea S, LaRussa P, Stockwell M. Factors associated with willingness to participate in a vaccine clinical trial among elderly Hispanic patients. Contemp Clin Trials Commun 2017;7:122. doi:10.1016/j.conctc.2017.06.010.

[17] Shim E, Chapman GB, Townsend JP, Galvani AP. The influence of altruism on influenza vaccination decisions. $\mathrm{J} \quad \mathrm{R} \quad \mathrm{Soc}$ Interface 2012;9:2234-43. doi:10.1098/rsif.2012.0115. 
[18] Ross S, Grant A, Counsell C, Gillespie W, Russell I, Prescott R. Barriers to participation in randomised controlled trials: a systematic review. J Clin Epidemiol 1999;52:1143-56.

[19] Sojka BN, Sojka P. The blood donation experience: self-reported motives and obstacles for donating blood. Vox Sang 2008;94:56-63. doi:10.1111/j.1423-0410.2007.00990.x.

[20] Raheja D, Davila EP, Johnson ET, Deović R, Paine M, Rouphael N. Willingness to Participate in Vaccine-Related Clinical Trials among Older Adults. Int J Environ Res Public Health 2018;15. doi:10.3390/ijerph15081743.

[21] Costas L, Bayas JM, Serrano B, Lafuente S, Muñoz M-A. Motivations for participating in a clinical trial on an avian influenza vaccine. Trials 2012;13:28. doi:10.1186/17456215-13-28.

[22] Ervine C. Directive 2004/39/Ec of the European Parliament and of the Council of 21 April 2004. Core Statut. Co. Law, London: Macmillan Education UK; 2015, p. 757-9. doi:10.1007/978-1-137-54507-7_21.

[23] Ramsey TM, Snyder JK, Lovato LC, Roumie CL, Glasser SP, Cosgrove NM, et al. Recruitment strategies and challenges in a large intervention trial: Systolic Blood Pressure Intervention Trial. Clin Trials Lond Engl 2016;13:319-30. doi:10.1177/1740774516631735.

[24] Newman PA, Logie C, James Ll, Charles T, Maxwell J, Salam K, et al. "Speaking the Dialect": Understanding Public Discourse in the Aftermath of an HIV Vaccine Trial Shutdown. Am J Public Health 2011;101:1749-58. doi:10.2105/AJPH.2011.300208.

[25] Benkimoun P. Essai clinique mortel de Rennes: un rapport pointe le manque d'information des volontaires. Le Monde.fr 2016.

[26] Yaqub O, Castle-Clarke S, Sevdalis N, Chataway J. Attitudes to vaccination: A critical review. Soc Sci Med 2014;112:1-11. doi:10.1016/j.socscimed.2014.04.018. 
[27] Lazcano-Ponce E, Rivera L, Arillo-Santillán E, Salmerón J, Hernández-Avila M, Muñoz 358 N. Acceptability of a human papillomavirus (HPV) trial vaccine among mothers of adolescents in Cuernavaca, Mexico. Arch Med Res 2001;32:243-7.

360

[28] Detoc M, Touche C, Charles R, Lucht F, Gagneux-Brunon A, Botelho-Nevers E. Primary physicians' attitudes toward their patients receiving a proposal to participate in a vaccine trial. Hum Vaccin Immunother. 2019 Jun 26:1-11.

363

364 
Table 1: Design of proposed vaccine trials (PVT)

\begin{tabular}{|c|c|c|c|c|c|c|c|c|c|c|c|}
\hline $\begin{array}{l}\text { Microorganism } \\
\text { targeted }\end{array}$ & Phase & $\begin{array}{l}\text { Healthy } \\
\text { volunteers } \\
\text { accepted }\end{array}$ & $\begin{array}{l}\text { Sexe } \\
\text { eligible for } \\
\text { study }\end{array}$ & Age & Site visit number & $\begin{array}{l}\text { Vaccine } \\
\text { Injection } \\
\text { number }\end{array}$ & $\begin{array}{l}\text { Financial } \\
\text { compensation }\end{array}$ & $\begin{array}{l}\text { Status of study } \\
\text { vaccine }\end{array}$ & $\begin{array}{l}\text { Sites of } \\
\text { investigation }\end{array}$ & $\begin{array}{l}\text { Number of } \\
\text { acceptating } \\
\text { people } \\
(\mathrm{n}=210)\end{array}$ & $\begin{array}{l}\text { Number of } \\
\text { declining } \\
\text { people } \\
(\mathrm{n}=131)\end{array}$ \\
\hline $\begin{array}{l}\text { Clostridium } \\
\text { difficile** }^{*}\end{array}$ & 3 & No & All & $\begin{array}{l}50 \text { years and } \\
\text { older }\end{array}$ & $\begin{array}{l}4 \text { or } 11 \text { depends } \\
\text { arm and phone } \\
\text { contact every two } \\
\text { weeks }\end{array}$ & 3 & Yes & Experimental & 1,3 & $\mathrm{n}=8(3.8 \%)$ & $\begin{array}{l}\mathrm{n}=36 \\
(27.5 \%)\end{array}$ \\
\hline $\begin{array}{l}\text { Streptococcus } \\
\text { pneumoniae }\end{array}$ & $2 b$ & No & All & $\begin{array}{l}18 \text { years and } \\
\text { older }\end{array}$ & 9 & $\begin{array}{l}2 \text { or } 3 \\
\text { (depends } \\
\text { arm) }\end{array}$ & No & Marketed & 3 & $\mathrm{n}=21(10 \%)$ & $\mathrm{n}=5(3.8 \%)$ \\
\hline $\begin{array}{l}\text { Staphylococcus } \\
\text { aureus }\end{array}$ & $2 b$ & No & All & $\begin{array}{l}18 \text { years to } \\
85 \text { years }\end{array}$ & $\begin{array}{l}5 \text { and } 1 \text { contact } \\
\text { phone }\end{array}$ & 1 & $\mathrm{No}^{*}$ & Experimental & 4,5 & $\mathrm{n}=48(22.9 \%)$ & $\begin{array}{l}\mathrm{n}=30 \\
(22.9 \%)\end{array}$ \\
\hline $\begin{array}{l}\text { Respiratory } \\
\text { Syncytial Virus }\end{array}$ & 2 & Yes & Female & $\begin{array}{l}18 \text { years to } \\
45 \text { years }\end{array}$ & 5 & 1 & Yes & Experimental & 1,2 & $\mathrm{n}=90(42.9 \%)$ & $\begin{array}{l}\mathrm{n}=37 \\
(28.2 \%)\end{array}$ \\
\hline Ebola virus** & 2 & Yes & All & $\begin{array}{l}18 \text { years to } \\
65 \text { years }\end{array}$ & $\begin{array}{l}11 \text { or } 12 \text { depends } \\
\text { arm }\end{array}$ & 2 & Yes & Experimental & 4 & $\mathrm{n}=2(1 \%)$ & $\mathrm{n}=0$ \\
\hline Pneumococcal & $2 b$ & No & All & $\begin{array}{l}18 \text { years to } \\
75 \text { years }\end{array}$ & 10 & 2 & No & Marketed & 3 & $\mathrm{n}=1(0.5 \%)$ & $\mathrm{n}=0$ \\
\hline Malaria & 1 & Yes & Female & $\begin{array}{l}18 \text { years to } \\
35 \text { years }\end{array}$ & $\begin{array}{l}9 \text { and } 6 \text { contact } \\
\text { phone }\end{array}$ & 3 & Yes & Experimental & 2 & $\mathrm{n}=15(7.1 \%)$ & $\mathrm{n}=0$ \\
\hline Shigella sonnei & 1 & Yes & All & $\begin{array}{l}22 \text { years to } \\
50 \text { years }\end{array}$ & 5 & 1 & Yes & Experimental & 2 & $\mathrm{n}=25(14.9 \%)$ & $\mathrm{n}=0$ \\
\hline Clostridium difficile & 3 & No & All & $\begin{array}{l}50 \text { years and } \\
\text { older }\end{array}$ & 6 & 3 & $\mathrm{No}^{*}$ & Experimental & 3 & $\mathrm{n}=0$ & $\begin{array}{l}\mathrm{n}=23 \\
(17.6 \%)\end{array}$ \\
\hline
\end{tabular}

* Reimbursement of travel costs

** Study was suspended during 1 year due to investigation on potential adverse events 
Table 2: Demographical characteristics of the panel population

\begin{tabular}{|c|c|c|c|c|}
\hline $\mathrm{n}(\%)$ & $\begin{array}{c}\text { Panel } \\
\text { population } \\
(\mathrm{n}=341)\end{array}$ & $\begin{array}{l}\text { Accepting } \\
\text { people } \\
(\mathrm{n}=\mathbf{2 1 0}) \\
\end{array}$ & $\begin{array}{l}\text { Declining } \\
\text { people }(n=131)\end{array}$ & $\mathbf{P}$ \\
\hline \multicolumn{4}{|l|}{ Site } & \multirow[t]{6}{*}{$<0.005$} \\
\hline 1 & $73(21.4)$ & $34(16.2)$ & $39(29.8)$ & \\
\hline 2 & $96(28.2)$ & $96(45.7)$ & $0(0.0)$ & \\
\hline 3 & $92(27)$ & $30(14.3)$ & $62(47.3)$ & \\
\hline 4 & $58(17)$ & $35(16.7)$ & $23(17.6)$ & \\
\hline 5 & $22(6.5)$ & $15(7.1)$ & $7(5.3)$ & \\
\hline Age & $\begin{array}{l}45.1 \pm 18.2 \\
(\mathrm{n}=320)\end{array}$ & $\begin{array}{l}38.5 \pm 14.5 \\
(\mathrm{n}=192)\end{array}$ & $\begin{array}{l}54.9 \pm 18.9 \\
(\mathrm{n}=128)\end{array}$ & $<0.005$ \\
\hline \multicolumn{4}{|l|}{ Gender } & \multirow[t]{3}{*}{0.204} \\
\hline Female & $235(68.9)$ & $150(71.4)$ & $85(64.9)$ & \\
\hline Male & $106(31.1)$ & $60(28.6)$ & $46(35.1)$ & \\
\hline \multicolumn{4}{|l|}{ Level of education } & \multirow[t]{2}{*}{$<0.005$} \\
\hline High level & $176(51.6)$ & $128(61)$ & $48(36.6)$ & \\
\hline To have children & $217(63.6)$ & $113(53.8)$ & $104(79.4)$ & $<0.005$ \\
\hline \multicolumn{4}{|l|}{$\begin{array}{l}\text { Distance between clinical trial } \\
\text { center and home }(n=207)\end{array}$} & \multirow[t]{5}{*}{0.259} \\
\hline$<10 \mathrm{~km}$ & $133(39.3)$ & $89(43)$ & $44(33.6)$ & \\
\hline Between 10 and $30 \mathrm{~km}$ & 83 (24.6) & $51(24.6)$ & $32(24.4)$ & \\
\hline Between 30 and $50 \mathrm{~km}$ & $29(8.6)$ & $15(7.2)$ & $14(10.7)$ & \\
\hline$>50 \mathrm{~km}$ & $93(27.5)$ & $52(25.1)$ & $41(31.3)$ & \\
\hline \multicolumn{4}{|l|}{ Clinical research awareness } & \multirow[t]{2}{*}{0.621} \\
\hline Yes & $224(66.9)$ & $135(65.9)$ & $89(68.5)$ & \\
\hline $\begin{array}{l}\text { Prior participation to a } \\
\text { clinical trial }\end{array}$ & $69(20.4)$ & $48(23.2)$ & $21(16)$ & 0.112 \\
\hline \multicolumn{5}{|l|}{ Study awareness by... } \\
\hline $\begin{array}{l}\text { Physician of the clinical center } \\
\text { team }\end{array}$ & $135(39.9)$ & $65(31.4)$ & $70(53.4)$ & $<0.005$ \\
\hline Other physician & $60(17.8)$ & $34(16.4)$ & $26(19.8)$ & 0.422 \\
\hline Poster & $8(2.4)$ & $6(2.9)$ & $2(1.5)$ & 0.419 \\
\hline Media & $10(3)$ & $10(4.8)$ & $0(0)$ & 0.011 \\
\hline Word of mouth & $29(8.6)$ & $24(11.6)$ & $5(3.8)$ & 0.013 \\
\hline Internet & $23(6.8)$ & $17(8.2)$ & $6(4.6)$ & 0.196 \\
\hline Postal letter & 37 (10.9) & $30(14.5)$ & $7(5.3)$ & 0.009 \\
\hline \multicolumn{5}{|l|}{$\begin{array}{l}\text { information (physician and } \\
\text { other) }\end{array}$} \\
\hline Study compensated & $213(62.5)$ & $140(66.7)$ & $73(55.7)$ & 0.042 \\
\hline Study phase & & & & $<0.005$ \\
\hline Phases 1 and $2 \mathrm{a}$ (early) & 169 (49.6) & $132(62.9)$ & $37(28.2)$ & \\
\hline Phases 2b, 3 (late) & $172(50.4)$ & $78(37.1)$ & $94(71.8)$ & \\
\hline \multicolumn{5}{|l|}{ Vaccination opinion } \\
\hline Positive opinion & $286(84.6)$ & $192(92.3)$ & $94(72.3)$ & $<0.005$ \\
\hline $\begin{array}{l}\text { Treating physician opinion } \\
\text { requested }\end{array}$ & $59(17.4)$ & $37(17.8)$ & $22(16.8)$ & 0.814 \\
\hline Opinion followed & $40(67.9)$ & $28(75.7)$ & $12(54.4)$ & \\
\hline $\begin{array}{l}\text { Opinion of those around you } \\
\text { requested }\end{array}$ & $140(41)$ & $82(39.2)$ & $60(46.5)$ & \\
\hline
\end{tabular}


Table 3: Univariate and multivariate analysis of factors associated with acceptance

Only participants on sites 1, 3, 4 and 5 were included in this analysis $(n=224)$.

Site 2 only included accepting people and was then not included in this analysis

\begin{tabular}{lcccc}
\hline Explanatory variables & $\begin{array}{c}\text { Univariate analysis } \\
\text { OR }(95 \% \mathrm{CI})\end{array}$ & $\mathrm{p}$ & $\begin{array}{c}\text { Multivariate analysis } \\
\text { aOR (95\% I })\end{array}$ & $\mathrm{p}$ \\
\hline Age OR for one year increase in age & $0.97(0.95-0.98)$ & $<0.005$ & $0.94(0.91-0.96)$ & $<0.005$ \\
Male gender & $1.25(0.74-2.09)$ & 0.399 & - & - \\
Having Children & $0.66(0.37-1.20)$ & 0.173 & $1.89(0.77-4.69)$ & 0.165 \\
Prior participation in a PVT & $0.92(0.46-1.85)$ & 0.818 & - & - \\
Clinical research awareness & $0.64(0.38-1.10)$ & 0.111 & $0.71(0.38-1.38)$ & 0.317 \\
Asking treating physician's opinion & $1.60(0.85-3.00)$ & 0.137 & $1.24(0.53-2.88)$ & 0.619 \\
Favorable opinion about vaccines & $3.04(1.49-6.23)$ & 0.002 & $4.98(1.88-13.2)$ & $<0.005$ \\
Multiples source of information & $0.09(0.01-0.75)$ & 0.006 & $0.09(0.01-0.77)$ & 0.028 \\
Higher level of education & $1.18(0.7-1.99)$ & 0.535 & - & - \\
Information by the physician of the & $0.72(0.43-1.20)$ & 0.206 & - & - \\
clinical research team & $1.10(0.63-1.92)$ & 0.726 & - & - \\
Early Phase & $0.48(0.28-0.80)$ & $<0.005$ & $0.16(0.07-0.37)$ & $<0.005$ \\
Financial incentives & & & & \\
\hline
\end{tabular}


Table 4: Motivations and barriers to participate in a PVT

\begin{tabular}{|c|c|c|c|c|}
\hline Motivations for accepting people & $\begin{array}{l}\text { All Respondents } \\
(\mathbf{n}=\mathbf{2 0 6}, \%)\end{array}$ & $\begin{array}{l}\text { Early-phase } \\
\text { trials proposal } \\
\text { (Healthy people } \\
(\mathrm{n}=131, \%))\end{array}$ & $\begin{array}{l}\text { Late-phase trials } \\
\text { proposal (Patients } \\
(\mathrm{n}=75, \%))\end{array}$ & $\mathbf{p}$ \\
\hline \multicolumn{5}{|l|}{$\begin{array}{l}\text { Reasons that would encourage you to consent to participate in a } \\
\text { preventive vaccine trial were... }\end{array}$} \\
\hline ...To help research/to do advance science & $192(93.2)$ & $123(93.9)$ & $69(92)$ & 0.603 \\
\hline ...To help neighbors/to protect others & $135(65.5)$ & $91(69.5)$ & $44(58.7)$ & 0.12 \\
\hline ...Because the study is compensated & $118(57.3)$ & $110(84)$ & $8(10.7)$ & $<0.005$ \\
\hline ...Because I feel at-risk for the disease/the topic & $81(39.3)$ & $45(34.4)$ & $36(48)$ & 0.054 \\
\hline ...To protect myself from the disease prevented by the vaccine & $80(38.8)$ & $42(32.1)$ & $38(50.7)$ & 0.008 \\
\hline \multicolumn{5}{|l|}{$\begin{array}{l}\text { Points that helped me make my decision to participate in a PVT } \\
\text { were... }\end{array}$} \\
\hline Quality of information provided by the physician & $145(70.4)$ & $89(67.9)$ & $56(74.7)$ & 0.319 \\
\hline Theme of the clinical trial & $124(60.2)$ & $88(67.2)$ & $36(48)$ & 0.007 \\
\hline Medical follow-up planned for this study & $120(58.2)$ & $76(58)$ & $44(58.7)$ & 0.927 \\
\hline Financial incentives if such were the case & $98(47.6)$ & $88(67.2)$ & $10(13.3)$ & $<0.005$ \\
\hline Possibility to withdraw at any time & $92(44.6)$ & $62(47.3)$ & $30(40)$ & 0.309 \\
\hline Opinion of my general practitioner or referent physician & $63(30.6)$ & $29(22.1)$ & $34(45.3)$ & $<0.005$ \\
\hline Opinion of my entourage/relatives & $59(28.6)$ & $39(29.8)$ & $20(26.7)$ & 0.635 \\
\hline Barriers for declining people & $\begin{array}{l}\text { All Respondents } \\
(\mathbf{n}=131, \%)\end{array}$ & $\begin{array}{l}\text { Early-phase } \\
\text { trials proposal } \\
\text { (Healthy people } \\
(\mathrm{n}=\mathbf{3 7}, \%))\end{array}$ & $\begin{array}{l}\text { Late-phase trials } \\
\text { proposal (Patients } \\
(\mathrm{n}=94, \%))\end{array}$ & $\mathbf{p}$ \\
\hline \multicolumn{5}{|l|}{$\begin{array}{l}\text { Reasons that would discourage you to consent to participate in a } \\
P V T \text { were... }\end{array}$} \\
\hline I'm afraid about side effects & $48(36.6)$ & $10(27)$ & $38(40.4)$ & 0.15 \\
\hline I don't have time to come to appointments & $38(29.0)$ & $18(48.6)$ & $20(21.3)$ & 0.002 \\
\hline I live too far away & $30(22.9)$ & $1(2.7)$ & $29(30.9)$ & 0.001 \\
\hline I'm afraid about components of the vaccine & $26(19.85)$ & $14(37.8)$ & $12(12.8)$ & 0.001 \\
\hline I'm not sure how effective the vaccine is & $19(14.50)$ & $10(27)$ & $9(9.6)$ & 0.011 \\
\hline
\end{tabular}


My entourage advised me against it

I don't trust studies promoted by pharmaceutical companies

I've been scared since trial drug in Rennes (France)

I'm not a guinea pig

I have a bad experience in the past

I do not want to participate in a research project

I'm against vaccination

I don't want to be injected with the product

My treating physician advised me not to participate

I'm afraid of needles

I feel that my interest comes after that of the realization of the study

I don't think I'm at risk of getting the disease affected by this vaccine

The study is not adequately compensated

Beliefs/Religion/Culture

Others

\begin{tabular}{l|l}
$15(11.45)$ & $3(8.1)$ \\
$15(11.45)$ & $0(0)$ \\
$13(9.92)$ & $0(0)$ \\
$9(6.87)$ & $0(0)$ \\
$5(3.82)$ & $1(2.7)$ \\
$12(9.16)$ & $0(0)$ \\
$13(9.92)$ & $4(10.8)$ \\
$13(9.92)$ & $2(5.4)$ \\
$5(3.82)$ & $0(0)$ \\
$3(2.29)$ & $2(5.4)$ \\
$3(2.29)$ & $0(0)$ \\
$0(0.00)$ & - \\
$0(0.00)$ & - \\
$0(0.00)$ & - \\
$24(18.32)$ & $1(2.7)$
\end{tabular}

$12(12.8)$

0.401

$15(16)$

0.010

$13(13.8) \quad 0.017$

$9(9.6)$

0.051

4 (4.3)

12 (12.8)

0.676

0.023

0.83

9 (9.6)

0.278

0.153

0.137

0.272

1 (1.1)

3 (3.2)

$23(24.7)$

0.003 